\title{
Influence of the Storage Duration at Different Temperatures on the Concentrations of Extractable Inorganic Soil Nutrients
}

\author{
Jamal T. Elfaki' ${ }^{1}$, Ahmed M. Nour ${ }^{2}$, Magboul M. Sulieman ${ }^{3 *}$, Mushtaha E. Ali ${ }^{4}$ \\ ${ }^{1}$ Faculty of Agriculture, Nile Valley University, Atbara, Sudan \\ ${ }^{2}$ Agricultural Research Corporation, Wad Medani, Sudan \\ ${ }^{3}$ Department of Soil and Environment Sciences, University of Khartoum, Khartoum, Sudan \\ ${ }^{4}$ General Administration of Natural Resource and Sustainable Development, Khartoum, Sudan \\ Email: "magboul@uofk.edu
}

Received 18 February 2016; accepted 2 May 2016; published 5 May 2016

Copyright (c) 2016 by authors and Scientific Research Publishing Inc.

This work is licensed under the Creative Commons Attribution International License (CC BY). http://creativecommons.org/licenses/by/4.0/

(c) (i) Open Access

\section{Abstract}

The influence of the short storage periods at different temperatures on the concentrations of extractable soil cations $\left(\mathrm{Ca}^{2+}, \mathrm{Mg}^{2+}, \mathrm{Na}^{+}\right.$and $\left.\mathrm{K}^{+}\right)$and anions $\left(\mathrm{Cl}^{-}, \mathrm{SO}_{4}^{-}\right.$and $\left.\mathrm{PO}_{4}^{-}\right)$has been investigated in nine soil samples from Nile river terraces at River Nile State, North of Sudan (17.82289 to $17.82389 \mathrm{~N}$ and 33.99974 to $34.02127 \mathrm{E}$ ). Each soil extract is divided into three treatments: $\mathrm{i})$ control (immediately analyzed); ii) storage for 10 days and; iii) storage for $\mathbf{3 0}$ days. Each treatment is replicated three times: i) storage at $10^{\circ} \mathrm{C}$; ii) storage at ambient laboratory temperature $\left(25^{\circ} \mathrm{C}\right)$ and; iii) storage at $45^{\circ} \mathrm{C}$ in incubator. Statistical analysis of results reveals that significant difference are found at level $(P<0.05)$ for $\mathrm{K}^{+}, \mathrm{Mg}^{2+}, \mathrm{Ca}^{2+}, \mathrm{Cl}^{-}, \mathrm{SO}_{4}^{-}$and $\mathrm{PO}_{4}^{-}(0.043,0.002,0.001,0.021,0.004$ and 0.001$)$ respectively at $25^{\circ} \mathrm{C}$ and $45^{\circ} \mathrm{C}$ and storage periods of 10 and 30 days. In contrast, significant difference is also found at level $(P<0.001)$ for soluble calcium, magnesium and sulphate. In addition, results also reveal that $\mathrm{SO}_{4}^{-}$concentrations are significantly decreased when the storage period exceeds 10 days and temperature more than $25^{\circ} \mathrm{C}$. Depending upon our study results; we conclude that, all extractable inorganic nutrients are clearly affected by storage periods at various temperatures, exception of $\mathrm{Na}^{+}$. Most cations and anions are increased significantly with increased of storage period and temperatures. We therefore highly recommend that the extractable inorganic soil nutrients should be rapidly analyzed in order to obtain accurate results; otherwise, the time between extraction and analysis should be carefully recorded which may help considerably interpreting data from various studies.

\footnotetext{
"Corresponding author.
} 


\section{Keywords}

\section{River Nile State, Extractable Soil Cations, Storage Period, Inorganic Nutrients}

\section{Introduction}

Soil chemistry changes through the time, as biological and chemical processes break down or combine compounds through the time. These processes change once the soil is removed from its natural ecosystem (flora and fauna that penetrate the sampled area) and environment (temperature, moisture, and solar light/radiation cycles). As a result, the chemical composition analysis accuracy can be improved if the soil is analyzed soon after its extraction [1].

The soil-fresh sample received in the laboratory should be analyzed directly after sampling for determination of nitrate, nitrite and ammonium. The chemical changes in the soil can be slowed during storage and transportation by freezing it. Air-drying can also preserve the soil sample for many months. Lag time between field sampling and analysis must be minimized. Otherwise, storage time will inevitably introduce an additional factor influencing analysis results [2].

Soil samples are often store before starting the physiochemical properties analysis. This can affect subsequent concentrations of extractable inorganic nutrients, including $\mathrm{NH}_{4}^{+}$and $\mathrm{NO}_{3}^{-}$[3], $\mathrm{K}^{+}$[4] and $\mathrm{SO}_{4}^{-}$[5]. Moreover, recent study reports that, at $10^{\circ} \mathrm{C}$ the values of soluble potassium $\left(\mathrm{K}^{+}\right)$, calcium $\left(\mathrm{Ca}^{2+}\right)$, and magnesium $\left(\mathrm{Mg}^{2+}\right)$ are increased to $10 \%[6]$.

Sample handling and storage are more important aspects of soil analysis than generally recognized. [7] presents data indicating problems associated with drying and storing soil samples and changes that occur under various sample and storage conditions.

In this study, we assessed the influence of short storage periods at different temperatures on the concentrations of extractable soil cations $\left(\mathrm{Ca}^{2+}, \mathrm{Mg}^{2+}, \mathrm{Na}^{+}\right.$and $\left.\mathrm{K}^{+}\right)$and anions $\left(\mathrm{Cl}^{-}, \mathrm{SO}_{4}^{-}\right.$and $\left.\mathrm{PO}_{4}^{-}\right)$in soils of the Nile river terraces at River Nile State, North of Sudan. We tested the hypotheses that i) extractable inorganic nutrients concentrations would be significantly change during different storage periods as well as different temperatures; ii) extractable inorganic nutrients concentrations would be positively correlated with soil formed at different time but derived from similar parent materials; iii) chloride $\left(\mathrm{Cl}^{-}\right)$and sulphate $\left(\mathrm{SO}_{4}^{-}\right)$concentrations would be most changed during storage periods at different temperatures.

\section{Materials and Methods}

\subsection{Site Description}

The study area is located in North of Atbara city, River Nile State, Sudan, with an altitude of (336 - 358 meters) above sea level. The study area covered about 8000 ha and is located where the coordinate is at 17.82289 to $17.82389 \mathrm{~N}$ and 33.99974 to $34.02127 \mathrm{E}$. According to [8], the study area falls within the arid climatic zone. The average annual rainfall varies from 0 to $<100 \mathrm{~mm}$. Mean maximum temperature of the hottest months (May and June) is $43^{\circ} \mathrm{C}$. Mean minimum temperature of the coldest month (January) is less than $13^{\circ} \mathrm{C}$. The mean annual relative humidity ranges between 15\% to 21\% (January to February), less than 15\% (March to June). The predominant natural vegetation in the study area consists of the following species: Tundub (Capparis decidua), Seyal (Acacia tortilis), Usher, Musket (Prosopis chilensis), Heglig (Balanites aegypiaca) and Seder (Zizyphus spina-christi). The calculated soil temperature regime is hyperthermic and soil moisture regime is arridic. According [9], the soils of the study area belong within Entisols and Aridisols orders.

\subsection{Soil Sampling and Preparation}

Nine soil samples were collected from different Nile river terraces at River Nile State, North of Sudan (Table 1). At each site, approximately $5 \mathrm{~kg}$ of soil sample was collected from the depth of $0-30 \mathrm{~cm}$ using an auger and kept in a plastic bag. In the laboratory, soil samples were air-dried and passed through a $2 \mathrm{~mm}$ mesh sieve to obtain the fine earth fraction. To estimate the influence of storage period at different temperatures on the concentrations of soluble cations and anions, a 1:5 soil suspension was shaken for 30 minutes, and then extracted 
Table 1. Description of samples sites in the study area and some physical and chemical properties.

\begin{tabular}{|c|c|c|c|c|c|c|c|c|c|}
\hline \multirow{2}{*}{ Site No. } & \multirow{2}{*}{ Description } & \multicolumn{2}{|c|}{ Location } & \multirow{2}{*}{$\begin{array}{l}\text { Elevation } \\
\text { (m-a.s.l) }\end{array}$} & \multicolumn{3}{|c|}{ Partial Size Distribution\% } & \multirow{2}{*}{$\begin{array}{c}\text { Texture } \\
\text { Class }\end{array}$} & \multirow{2}{*}{$\begin{array}{c}\mathrm{CaCO}_{3} \\
(\%)\end{array}$} \\
\hline & & $\mathbf{N}$ & E & & Sand & Silt & Clay & & \\
\hline 1 & First Terrace & 17.81779 & 33.99229 & 349 & 48.38 & 47.77 & 3.85 & $\begin{array}{l}\text { Sandy } \\
\text { Loam }\end{array}$ & 5.50 \\
\hline 2 & $\begin{array}{c}\text { Second Terrace } \\
\text { (Farm of Agric. College) }\end{array}$ & 17.82389 & 33.99974 & 353 & 86.12 & 12.13 & 1.75 & Sand & 2.58 \\
\hline 3 & $\begin{array}{l}\text { Second Terrace } \\
\text { (Instructional Farm) }\end{array}$ & 17.82289 & 34.02127 & 358 & 32.61 & 61.14 & 6.25 & Silt Loam & 7.40 \\
\hline
\end{tabular}

with filter paper (Whatman No. 42). Each soil extract then divided into three treatments: i) control (time zero) or immediately analyzed); ii) storage for 10 days and; iii) storage for 30 days. Each treatment was replicated three times: i) storage at $10^{\circ} \mathrm{C}$; ii) storage at ambient laboratory temperature $\left(25^{\circ} \mathrm{C}\right)$ and; iii) storage at $45^{\circ} \mathrm{C}$ in incubator.

\subsection{Estimation of Soil Properties}

The particle size distribution of the subsamples was determined using Particle size analyzer model (Mastersizer 2000, Malvern) and the soil texture class was determined using USDA Textural triangle [10]. Soil pH was measured in 1:5 soil suspensions using a digital pH meter Model (3510, Jenway) and the results were compared according to the classification of [11]. The electrical conductivity $\left(\mathrm{EC} \mathrm{dS} / \mathrm{m}\right.$ at $\left.25^{\circ} \mathrm{C}\right)$ was determined in $1: 5$ soil extract using a conductivity meter Model (4510, Jenway) [12] and the results were compared according to the classification of [13]. Percent calcium carbonate $\left(\% \mathrm{CaCO}_{3}\right)$ was estimated by Calcimeter. The samples were treated with $0.1 \mathrm{~N}$ HCL; the volume of $\mathrm{CO}_{2}$ from pure calcium carbonate and samples were recorded. The percent calcium carbonate was then calculated according to [14]. Extractable cations $\left(\mathrm{Ca}^{2+}, \mathrm{Mg}^{2+}, \mathrm{Na}^{+}\right.$and $\left.\mathrm{K}^{+}\right)$and anions $\left(\mathrm{Cl}^{-}, \mathrm{SO}_{4}^{-}\right.$and $\left.\mathrm{PO}_{4}^{-}\right)$were determined in $1: 5$ soil extraction.

\subsection{Statistical Analysis}

Changes during storage period at 10 and 30 days were determined by repeated measures analysis of variance using storage period and treatment $\left(10^{\circ} \mathrm{C}, 25^{\circ} \mathrm{C}\right.$ and $\left.40^{\circ} \mathrm{C}\right)$ as factors. Values for fresh extracts (control) were compared with those from extracts stored for 10 and 30 days by one-way analysis of variance with Turkey's significant difference test for mean separation $(P<0.05)$. All statistical analysis was performed using SPSS software version 16.0 (SPSS Inc, USA).

\section{Results and Discussion}

\subsection{Selected Chemical and Physical Properties}

The description of the samples sites in the study area and some of the physical and chemical properties are presented in Table 1 and Table 2 respectively. The soil texture ranged from sandy loam in the first terrace, silt loam in the second terrace (Instructional farm). While the soil texture in the Agricultural College farm was sand. This could be due to the fact that these soils falls in the mining area which are truncated soils. The soils of the study area were moderately calcareous and the $\% \mathrm{CaCO}_{3}$ ranged from $2.58 \%$ to $7.40 \%$. The soil reaction (Soil $\mathrm{pH}$ ) varied from alkaline to strongly alkaline with a $\mathrm{pH}$ value ranged from 7.46 to 8.80 [11]. According to [13], the soils of the study area were non-saline and the electrical conductivity $\left(\mathrm{EC}_{\mathrm{e}}\right)$ ranged from 0.22 to $0.57 \mathrm{dS} / \mathrm{m}$. The predominant soluble cations and anions in the study area were $\left(\mathrm{Na}^{+}\right.$and $\left.\mathrm{Ca}^{++}\right),\left(\mathrm{HCO}_{3}^{-}\right.$and $\left.\mathrm{Cl}^{-}\right)$respectively.

\subsection{Influence of the Storage Period on the Concentrations of Extractable Nutrients}

Comparing first and second storage period there were significant difference at $P<0.05$ found in all estimated cations (Table 3 and Figure 1) respectively, except for $\mathrm{Na}^{+}$and $\mathrm{K}^{+}$. The $\mathrm{Ca}^{2+}$ and $\mathrm{Mg}^{2+}$ concentrations were significantly increased from $11.22 \pm 1.978^{\mathrm{a}}$ to $17.503 \pm 4.047^{\mathrm{b}}$ and from $3.790 \pm 2.794^{\mathrm{a}}-5.568 \pm 3.722^{\mathrm{b}}$ respectively. Similar trend were found when comparing 10 days with 30 days storage period, $\mathrm{Ca}^{2+}$ and $\mathrm{Mg}^{2+}$ concentrations were significantly increased from $17.503 \pm 4.047^{\mathrm{b}}$ to $23.505 \pm 5.998^{\mathrm{c}}$ in addition to $\mathrm{K}^{+}$concentration 


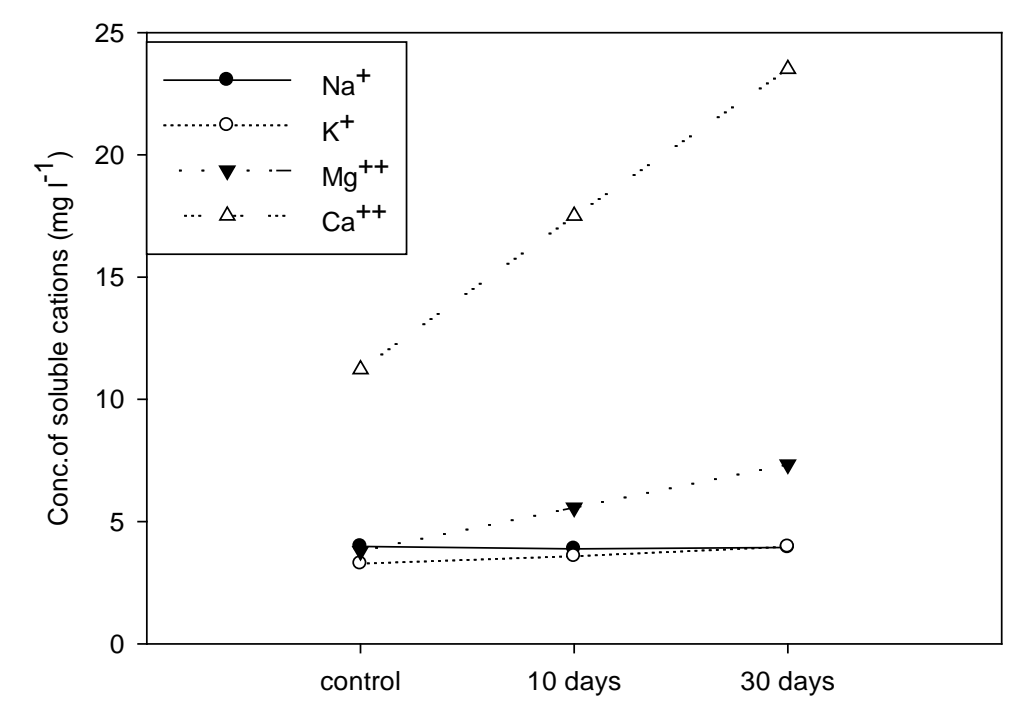

Figure 1. Change in soluble soil cations concentrations at different storage periods.

Table 2. Selected soil chemical properties of soils of the study area.

\begin{tabular}{ccccccccccccc}
\hline \multirow{2}{*}{$\begin{array}{c}\text { Site } \\
\text { No. }\end{array}$} & $\begin{array}{c}\mathrm{pH} \\
(1: 5)\end{array}$ & $\begin{array}{c}\mathrm{EC} \\
(\mathrm{dS} / \mathrm{m})\end{array}$ & $\mathrm{Na}^{+}$ & $\mathrm{K}^{+}$ & $\mathrm{Mg}^{++}$ & $\mathrm{Ca}^{++}$ & $\mathrm{PO}_{4}^{-}$ & $\mathrm{Cl}^{-}$ & $\mathrm{NO}_{3}^{-}$ & $\mathrm{SO}_{4}^{-}$ & $\mathrm{HCO}_{3}^{-}$ \\
\hline 1 & 8.73 & 0.219 & 1.699 & 0.547 & 0.196 & 0.558 & 0.050 & 0.538 & 0.090 & 0.290 & 2.193 \\
2 & 8.46 & 0.250 & 1.106 & 0.281 & 0.503 & 0.640 & 0.063 & 0.575 & 0.460 & 0.186 & 1.377 \\
3 & 8.80 & 0.570 & 2.811 & 0.248 & 0.172 & 0.352 & 0.057 & 0.522 & 0.081 & 0.643 & 2.424 \\
\hline
\end{tabular}

Table 3. Influence of storage period on the concentrations of soluble soil cations.

\begin{tabular}{cccc} 
& & & Treatments (storage period) \\
\cline { 2 - 4 } Cations & Time zero & 10 days & 30 days \\
\hline $\mathrm{Na}^{+}$ & $3.984 \pm 5.675^{\mathrm{a}}$ & $3.881 \pm 5.6636^{\mathrm{a}}$ & $3.943 \pm 5.733^{\mathrm{a}}$ \\
$\mathrm{K}^{+}$ & $3.279 \pm 1.243^{\mathrm{a}}$ & $3.582 \pm 1.306^{\mathrm{a}}$ & $3.968 \pm 1.430^{\mathrm{b}}$ \\
$\mathrm{Mg}^{2+}$ & $3.790 \pm 2.794^{\mathrm{a}}$ & $5.568 \pm 3.722^{\mathrm{b}}$ & $7.334 \pm 4.739^{\mathrm{c}}$ \\
$\mathrm{Ca}^{2+}$ & $11.22 \pm 1.978^{\mathrm{a}}$ & $17.503 \pm 4.047^{\mathrm{b}}$ & $23.505 \pm 5.998^{\mathrm{c}}$ \\
\hline
\end{tabular}

Means in each row with different letters are significantly different at $P<0.05$.

which increased from $3.582 \pm 1.306^{\mathrm{a}}$ to $3.968 \pm 1.430^{\mathrm{b}}$. These obtained results were expected specially increasing the storage period logically content in soluble solution. When we compared first and third storage period there were significant difference found in $\mathrm{K}^{+}$and highly significant difference observed in $\mathrm{Mg}^{2+}$ (from $3.790 \pm$ $2.794^{\mathrm{a}}$ to $7.334 \pm 4.739^{\mathrm{c}}$ ) and $\mathrm{Ca}^{++}$(from $11.22 \pm 1.978^{\mathrm{a}}$ to $23.505 \pm 5.998^{\mathrm{c}}$ ) at $P<0.05$ level. [15] reported that extractable $\mathrm{Ca}^{2+}, \mathrm{K}^{+}$, and $\mathrm{Mg}^{2+}$ were less influenced by storage period, although the effects varied among soil types.

In anions part (Table 4 and Figure 2) respectively, while comparing first and second period results shown that $\mathrm{Cl}^{-}$and $\mathrm{PO}_{4}^{-}$concentrations were significantly increased from $0.318 \pm 3.553^{\mathrm{a}}$ to $0.749 \pm 1.498^{\mathrm{b}}$ and $0.808 \pm$ $3.550^{\mathrm{a}}$ to $0.885 \pm 5.710^{\mathrm{b}}$ respectively. However, $\mathrm{SO}_{4}^{-}$concentrations were highly significant decreased (from $12.67 \pm 2.158^{\mathrm{a}}$ to $3.577 \pm 3.186^{\mathrm{c}}$ ) with increased of storage period. Similar results were obtained by [15]. Contrasting, [16] reported that soil storage before separation of the soil solution by centrifugation caused a marked decline in $P$ concentrations.

\subsection{Influence of Temperatures on the Concentrations of Extractable Nutrients}

Comparing first and second temperature $\left(10^{\circ} \mathrm{C}\right.$ and $\left.25^{\circ} \mathrm{C}\right)$, significant different were found in $\mathrm{Mg}^{2+}$ and $\mathrm{Ca}^{2+}$ 


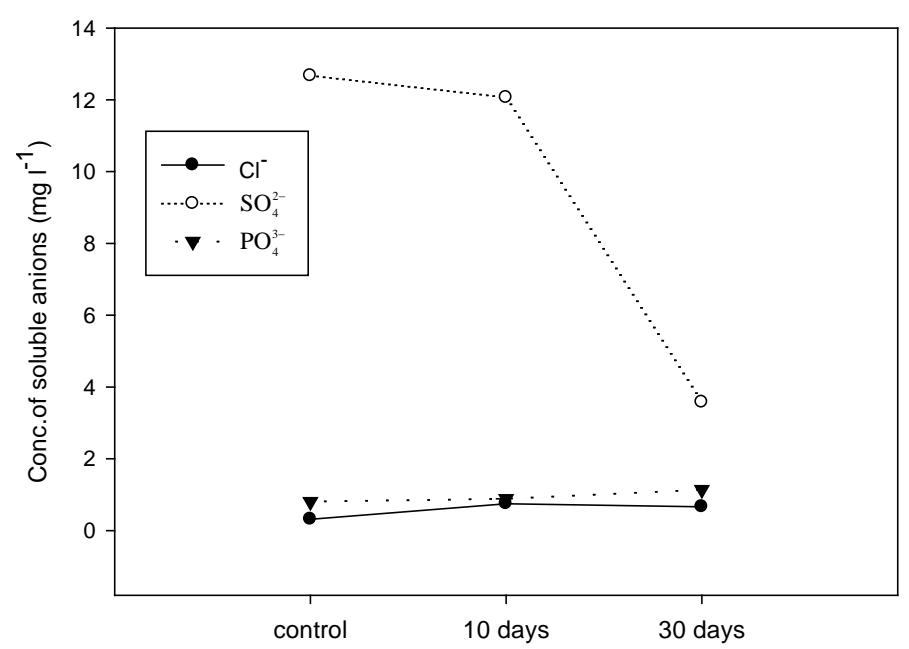

Figure 2. Change in soluble soil anions concentrations at different storage periods.

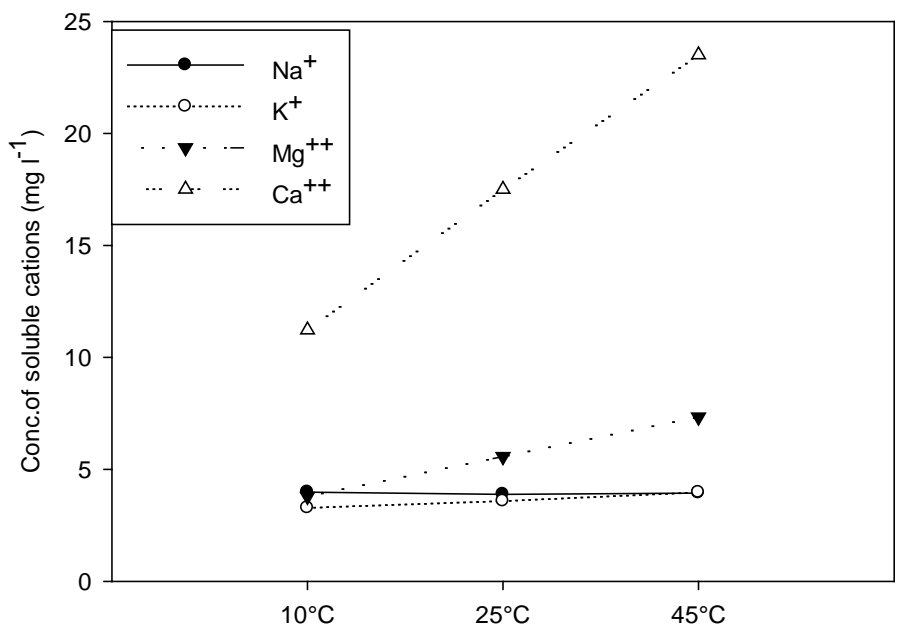

Figure 3. Change in soluble anions concentrations at different temperatures.

Table 4. Influence of storage period on the concentrations of soluble soil anions.

\begin{tabular}{cccc}
\hline & \multicolumn{3}{c}{ Treatments (storage period) } \\
\cline { 2 - 4 } Anions & Time zero & 10 days & 30 days \\
\hline $\mathrm{Cl}^{-}$ & $0.318 \pm 3.553^{\mathrm{a}}$ & $0.749 \pm 1.498^{\mathrm{b}}$ & $0.664 \pm 1.631^{\mathrm{b}}$ \\
$\mathrm{SO}_{4}^{-}$ & $12.67 \pm 2.158^{\mathrm{a}}$ & $12.063 \pm 2.120^{\mathrm{a}}$ & $3.577 \pm 3.186^{\mathrm{c}}$ \\
$\mathrm{PO}_{4}^{-}$ & $0.808 \pm 3.550^{\mathrm{a}}$ & $0.885 \pm 5.710^{\mathrm{b}}$ & $1.143 \pm 5.586^{\mathrm{b}}$ \\
\hline
\end{tabular}

*Means in each row with different letters are significantly different at $P<0.05$.

from $3.790 \pm 1.452^{\mathrm{a}}$ to $5.568 \pm 1.934^{\mathrm{b}}$ and $11.22 \pm 1.028^{\mathrm{a}}$ to $17.503 \pm 2.103^{\mathrm{b}}$ respectively. Similarly significant different are found while comparing $\mathrm{K}^{+}$in second and third temperature $\left(25^{\circ} \mathrm{C}\right.$ and $\left.45^{\circ} \mathrm{C}\right)$, and highly significant different were found while comparing second and third temperature in $\mathrm{Mg}^{2+}$ and $\mathrm{Ca}^{2+}$ respectively (Table 5 and Figure 3). Similar results were obtained by [15]. Additionally, change in $\mathrm{K}^{+}$and $\mathrm{Ca}^{2+}$ concentrations during low temperature storage were observed to be less significant and associated with soil types [17].

Comparing first and second temperature $\left(10^{\circ} \mathrm{C}\right.$ and $\left.25^{\circ} \mathrm{C}\right)$, significant different were found in $\mathrm{Cl}^{-}$and $\mathrm{PO}_{4}^{-}$ from $0.318 \pm 0.185^{\mathrm{a}}$ to $0.749 \pm 0.779^{\mathrm{b}}$ and $0.808 \pm 1.844^{\mathrm{a}}$ to $0.885 \pm 2.967^{\mathrm{b}}$ respectively. [14], in their study reported that, extractable $\mathrm{PO}_{4}$ of Refrigerated samples always contained lower values than counterparts stored at 
room temperature. They also pointed out that, extractable $\mathrm{PO}_{4}^{-}$were significantly differences among the soil types. Moreover, the amounts of extractable $\mathrm{PO}_{4}^{-}$were significantly increased during low temperature storage [15]. In contrast, [17], reported that soil storage before separation of the soil solution by centrifugation caused a marked decline in $\mathrm{P}$ concentrations, including those of molybdate-reactive $P$ and dissolved organic $P$, within a few days. However, $\mathrm{SO}_{4}^{-}$concentrations were significantly influenced by increased temperature (Table 6 and Figure 4).

\section{Conclusion}

Depending on our results, all investigated cations and anions were clearly affected by storage periods at various temperatures, exception of $\mathrm{Na}^{+}$. Most cations and anions were increased significantly with increased of storage period and temperatures, while some anions (such as $\mathrm{SO}_{4}^{-}$and $\mathrm{Cl}^{-}$) were dramatically decreased with increased of storage period and temperatures. Despite the simplicity of this research and some limitations such as design which was performed, but the obtained results confirmed that the storage periods and temperatures were influenced markedly on the concentrations of different extractable inorganic soil nutrients. We therefore highly

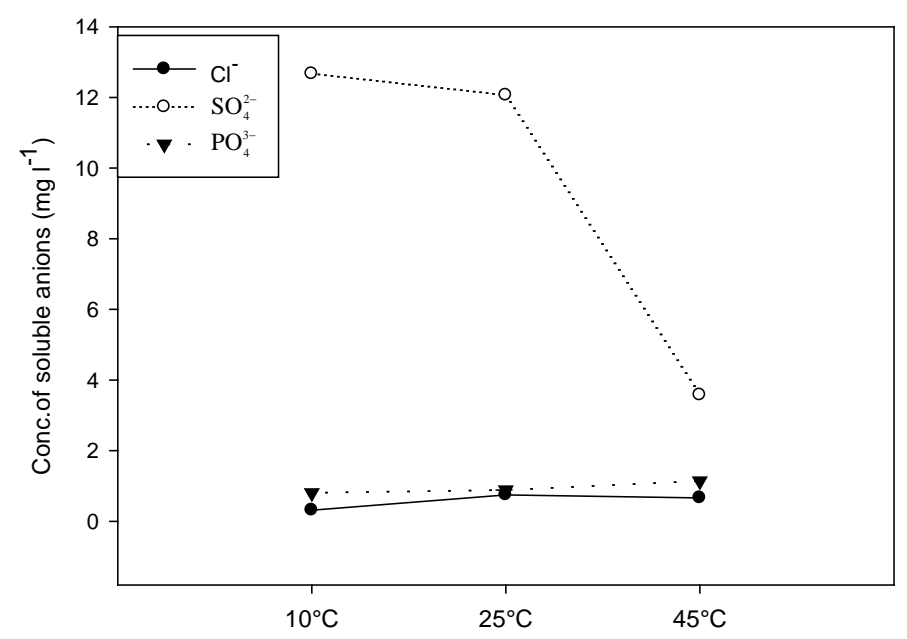

Figure 4. Change in soluble anions concentrations at different temperatures.

Table 5. Influence of storage period on the concentrations of soluble soil anions.

\begin{tabular}{cccc} 
& & \multicolumn{3}{c}{ Treatments (storage period) } \\
\cline { 2 - 4 } Cations & $10^{\circ} \mathrm{C}$ & $25^{\circ} \mathrm{C}$ & $45^{\circ} \mathrm{C}$ \\
\hline $\mathrm{Na}^{+}$ & $3.984 \pm 29.49^{\mathrm{a}}$ & $3.881 \pm 29.426^{\mathrm{a}}$ & $3.943 \pm 29.794^{\mathrm{a}}$ \\
$\mathrm{K}^{+}$ & $3.279 \pm 0.645^{\mathrm{a}}$ & $3.582 \pm 0.679^{\mathrm{a}}$ & $3.968 \pm 0.743^{\mathrm{b}}$ \\
$\mathrm{Mg}^{++}$ & $3.790 \pm 1.452^{\mathrm{a}}$ & $5.568 \pm 1.934^{\mathrm{b}}$ & $7.334 \pm 2.463^{\mathrm{c}}$ \\
$\mathrm{Ca}^{++}$ & $11.22 \pm 1.028^{\mathrm{a}}$ & $17.503 \pm 2.103^{\mathrm{b}}$ & $23.505 \pm 3.117^{\mathrm{c}}$ \\
\hline
\end{tabular}

*Means in each row with different letters are significantly different at $P<0.05$.

Table 6. Influence of temperature on different concentrations of soluble anions.

\begin{tabular}{cccc} 
& & \multicolumn{2}{c}{ Treatments (temperature) } \\
Anions & $10^{\circ} \mathrm{C}$ & $25^{\circ} \mathrm{C}$ & $45^{\circ} \mathrm{C}$ \\
\hline $\mathrm{Cl}^{-}$ & $0.318 \pm 0.185^{\mathrm{a}}$ & $0.749 \pm 0.779^{\mathrm{b}}$ & $0.664 \pm 0.848^{\mathrm{b}}$ \\
$\mathrm{SO}_{4}^{-}$ & $12.67 \pm 11.21^{\mathrm{a}}$ & $12.063 \pm 11.02^{\mathrm{a}}$ & $3.577 \pm 1.314^{\mathrm{c}}$ \\
$\mathrm{PO}_{4}^{-}$ & $0.808 \pm 1.844^{\mathrm{a}}$ & $0.885 \pm 2.967^{\mathrm{b}}$ & $1.143 \pm 2.902^{\mathrm{b}}$ \\
\hline
\end{tabular}

"Means in each row with different letters are significantly different at $P<0.05$. 
recommended that the extracted inorganic soil nutrients should be rapidly analyzed in order to obtain the accurate results.

\section{Acknowledgements}

The authors are greatly indebted to dean of Agriculture College and general manager of Educational Farm, Nile Valley University.

\section{References}

[1] Boczulak, S.A., Hawkins, B.J. and Roy, R. (2014) Temperature Effects on Nitrogen Form Uptake by Seedling Roots of Three Contrasting Conifers. Tree Physiology, 5, 513-523.

[2] International Center for Agricultural Research in the Dry Areas (2013) Methods of Soil, Plant, and Water Analysis: A Manual for the West Asia and North Africa Region George.

[3] Mulvaney, R.L. (1996) Nitrogen-Inorganic Forms. In: Sparks, D.L., et al., Eds., Methods of soil analysis. Part 2. Chemical Properties, Soil Science Society of America, Madison, Wisconsin, USA, 1123-1184.

[4] Luo, J.X. and Jackson, M.L. (1985) Potassium Release on Drying of Soil Samples from a Variety of Weathering Regimes and Clay Mineralogy in China. Geoderma, 35, 197-208.

[5] Comfort, S.D., Dick, R.P. and Baham, J. (1991) Air-Drying and Pretreatment Effects on Sulfate Sorption. Soil Science Society of America Journal, 55, 968-973.

[6] Masashi, et al. (1999) Development of a New Multinutrient Extraction Method for Macro- and Micro-Nutrients in Arable Land Soil. Soil Science \& Plant Nutrition, 46, 299-313.

[7] Richmond, B. and James, B. (1980) Studying Dried, Stored Soil Samples—Some Pitfalls. Soil Science Society of America Journal, 44, 721-724. http://dx.doi.org/10.2136/sssaj1980.03615995004400040011x

[8] Van der Kevie, W. (1973) Climate Zones in the Sudan. Soil Survey Department, Wad Medani.

[9] Soil Survey Staff (2014) Keys to Soil Taxonomy. 12th Edition, United States Department of Agriculture, Natural Resources Conservation Service, Lincoln, 97, 123, 287.

[10] Soil Survey Staff (2014) Kellogg Soil Survey Laboratory Methods Manual. In: Burt, R. and Soil Survey Staff, Eds., Soil Survey Investigations Report No. 42, Version 5.0, US Department of Agric. Natural Resources Conservation Service, Lincoln.

[11] Marx, E.S., Hart, J. and Stevens, R.G. (1999) Soil Test Interpretation Guide. Oregon State University, 1-8.

[12] U.S. Salinity Lab. Staff (1954) Diagnosis and Improvement of Saline and Alkali Soils. Agricultural Handbook No. 60, United State Department of Agriculture.

[13] Rhoades, J.D. (1996) Salinity: Electrical Conductivity and Total Dissolved Solids. In: Sparks, R.L., Ed., Methods for Soil Analysis, Part 3: Chemical Methods, Soil Science Society of America, Madison, 417-435.

[14] Horváth, B., Opara-Nadi, O. and Beese, F. (2005) A Simple Method for Measuring the Carbonate Content of Soils. Soil Science Society of America Journal, 69, 1066-1068.

[15] Turner, B.L. and Romero, T.E. (2009) Short-Term Changes in Extractable Inorganic Nutrients during Transport and Storage of Tropical Rain Forest Soils. Soil Science Society of America Journal, 73, 972-1979.

[16] Chapman, P.J., Shand, C.A., Edwards, A.C. and Smith, S. (1997) Effect of Storage and Sieving on the Phosphorus Composition of Soil Solution. Soil Science Society of America Journal, 61, 315-321.

[17] Allen, S.E. and Grimshaw, H.M. (2006) Effect of Low Temperature Storage on the Extractable Ions in Soils. Journal of the Science of Food and Agriculture, 13, 525-529. 